\title{
Comparison of Drying Characteristics of Seedless Grapes (Vitis vinifera L.) Using Solar Dehydrator and Natural-Sun-Dehydration Elnemr, M. K. ${ }^{1}$; A. M. El-Sheikha ${ }^{1}$; Ghada A. Mosad $^{2}$ and Nada H. Mohamed ${ }^{1}$ ${ }^{1}$ Agricultural Engineering Dept., Faculty of Agriculture, Demitta University \\ ${ }^{2}$ Agricultural Engineering Dept., Faculty of Agriculture, Mansoura University
}

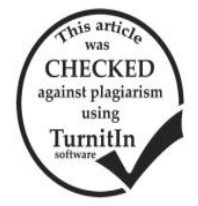

\section{ABSTRACT}

This study attempts to compare the dehydrating characteristics of pretreated seedless grapes using two different modes of dehydrating (Modified-Quonset dehydrator and Natural-sun-drying) under climatic conditions of Mansoura University $\left(31.043^{\circ} \mathrm{N}\right.$ and $31.352^{\circ} \mathrm{E}$ ). Solar dehydrating systems for drying agricultural products have clarified to be practical, saving energy and time, economical, and the responsible approach environmentally. Different measurements of macroclimatic parameters (incident solar radiation, air temperature, relative humidity, and wind speed) and microclimatic parameters (incident solar radiation, air temperature, bulk temperature of grape berries, and air relative humidity) had monitored, measured and recorded during the experimental work. The thermal performance analysis for the solar dehydrator, drying characteristics of thin layer of pretreated seedless grapes, and quality of raisins produced from two different modes of dehydrating were tested and evaluated. During the experimental work, the hourly average incident solar radiation outside was $673.8 \mathrm{~W} / \mathrm{m} 2( \pm 214.2)$, while that amount inside the solar dryer was $588.9( \pm 220.9)$, which achieved an hourly average effective transmittance of polycarbonate cover of $87.40 \%( \pm 6.9)$. The hourly average air temperatures outside and inside solar dehydrator during was $31.0( \pm 2.0)$, and $49.9( \pm 10.1)$. Accordingly, the increasing percentage in dehydrating-air-temperature was $61.25 \%$. The hourly average air-relative-humidity inside the solar dehydrator was $26.4 \%( \pm 1.40)$, whilst, the outside air-relative humidity was $63.7 \%$ ( \pm 3.6 ). Consequently, solar dehydrator reduced the air-relative-humidity under the outside by $37.3 \%$. The overall thermal efficiency of the solar dehydrator was $72.21 \%$, while, the drying efficiency of the solar dehydrator was $56.48 \%$. As a result, about $27.79 \%$ of the total heating power was lost with the exhausted air. The initial moisture content of pretreated seedless grapes prior to the drying process was $77.19 \%$ w.b. ( \pm 0.65 w.b.). During the drying process, the drying time, drying rate, and quantity of produced raisins for the Modified-Quonset and Natural-sun-dehydrating, respectively, was 49 and 66 hours, 574.7 and $434.1 \mathrm{~g} / \mathrm{hr}$., and $6.840 \mathrm{and}$ $6.785 \mathrm{~kg}$ of raisins. Accordingly, each one kilogram of raisins requires 4.902 and $5.158 \mathrm{~kg}$ of fresh grapes, respectively. The solar dehydrator increased the rehydration ratio by $12.28 \%$ as compared with the Natural-sun-drying system. The total carbohydrates contained in the fresh seedless grapes $(462.4 \mathrm{mg} / \mathrm{g}$ ) decreased into 393.71 and $339.70 \mathrm{mg} / \mathrm{g}$ due to drying process, respectively. The concentration of sugar contained in fresh grapes $(409.8 \mathrm{mg} / \mathrm{g}$ reduced in raisins and reached into 341.32 and $329.68 \mathrm{mg} / \mathrm{g})$, respectively. Main contained of Vitamin C in raisins had also affected by the drying process with a $24.61 \%$ and $35.28 \%$ reduction for the two different modes of dehydrating, respectively.

\section{INTRODUCTION}

Solar energy is a tried, proven, and renewable source of energy, particularly for low temperature heating. The energy source for agricultural applications is depending on the development of solar energy system that have optimum thermal performance, good reliability, and economic characteristics that compare favourably with conventional energy systems and other energy sources. This development must reach a point where satisfactory thermal performance and reliability can achieve for numerous solar energy applications. To be economical, the solar energy systems must have high annual utilisation, relatively long life, and properly designed for the location and nature of the specific application to realistically evaluate the solar energy as alternate energy source. Solar energy is therefore, considered as a heat source for numerous crops drying that received considerable attention in recent years owing to uncertain price rise of fossil fuel and its possibility to depletion (Fudholi et al., 2015: Ramos et al., 2015; Abdellatif et al., 2015).

Most developing countries cannot produce and provide enough agricultural products to support and meet their upsurge populations. A considerable percentage of agricultural productions in most of these areas rapidly deteriorate in quality after harvest due to poor or nonexistent processing and storage facilities. A high field losses annually occurred because the most crops are usually left to dry slowly in the open fields under heavy insects, rodent attack, and fluctuation of weather conditions. Most agricultural products for storage must firstly be dehydrated so that it can be kept the quality of the final products for a long-time (Fudholi et al., 2013). As an alternative to Natural-sun-drying, solar dehydrators are attractive and promising different applications of solar energy systems. This type of energy system is a renewable and environmentally friendly technology. Appropriate design of greenhouse solar dehydrators permit and provide a highly degree of control during the dehydration process than the other dehydrators. This system of dehydration considered as the best one for drying large scale of agricultural products (Jairaj et al., 2009). Using solar dehydrating for the agricultural products, the moisture content removed by the hot air mainly heated by solar energy, which having temperature ranged between 50 to $60^{\circ} \mathrm{C}$ (Kumar et al., 2016).

Egypt is one of the countries that have significantly increased the production of grapes over the period of 20002015. In 2014, Egypt was the fourth world producer with $5 \%$ share of production worldwide. Total cultivated area with grapes in Egypt estimated to be 197,000 feddan in 2015 , with 178,000 feddan grapes fruited (table grapes) area, that representing about $13.2 \%$ of the total area of fruits. The productivity of grapes in Egypt is about $1,687,000$ tons, which representing about $15.1 \%$ of fruits production in 2015. Approximately $56.2 \%$ of the total production in Egypt is being yield in Nubaria region (FAO, 2017). In spite of that, Egypt annually imports around 600 tons of dried grapes (raisins) with total value of $\$ 8.8$ million as occurred in 2015. At the same time, exported quantity of dried grapes was only 51.6 tons with an economic value of $\$ 157,000$. The growth rate of imported quantity of raisin to Egypt from the word estimated is 3.1\% during the period from 2001 to 2015 . While the growth rate of dried grapes in the world estimated about $1.2 \%$ during the same period. Thus, there are possibilities to 
reduce the imported quantities of raisins by increasing processing along with reducing the losses and waste in grapes value chain. In some cases, post-harvest losses of fresh fruits and vegetables account more than $50 \%$ in developing countries. However, these losses have drastically reduced by preservation. Beside, dried fruits and vegetable have number of applications similar to the fresh fruits (FAO, 2017). An advantage being that, reduction in weight, volume, packaging, storage, and transportation costs. The moisture content of fresh grapes is namely ranges from 78 to $80 \%$ w.b., while, the dried product (raisins) must contains only about $15-18 \%$ w.b. of moisture content.

The primary objective of this study is to compare between two different methods for dehydrating pre-treated seedless grapes during July and August 2018. This research work was executed in the station of agricultural researches and experiments, Faculty of Agriculture, University of Mansoura at latitude angle of $31.043^{\circ} \mathrm{N}$, longitude angle of $31.352^{\circ} \mathrm{E}$, and mean altitude above the sea level of $6.72 \mathrm{~m}$ during the late of July (29/7/2018) until $5^{\text {th }}$ of August 2018.

\section{MATERIALS AND METHODS}

\section{Description of solar dehydrator}

It consists of a heating space for heating the dehydrating air, and a drying chamber. The heating space is parallel rectangular in shape, which had a cover of semicylindrical to constitute the modified-Quonset architectural form. The structural frame was made of $12.7 \mathrm{~mm}$ diameter hot dipped galvanized pipes with excellent anti-corrosion. It was $2.0 \mathrm{~m}$ long, $1.0 \mathrm{~m}$ wide, $0.4 \mathrm{~m}$ high of vertical sidewalls, $0.3 \mathrm{~m}$ high of semi-circular curved end, $1.26 \mathrm{~m}$ long of arc, $0.70 \mathrm{~m}$ high of eaves, net dehydration surface area of $2.0 \mathrm{~m}^{2}$, and net air volume of $1.20 \mathrm{~m}^{3}$. An air chamber had also made up of double layer of $2.0 \mathrm{~mm}$ thick firm galvanized sheet with $2.5 \mathrm{~cm}$ space between at which it filled using loosely packed rock-wool insulation to minimize the heat energy loss or gain. The solar dehydrator was covered using polycarbonate sheet $2.0 \mathrm{~mm}$ thick antiUV. Dehydrator was equipped by air blower (0.5-hp electric motor power, speed of $3000 \mathrm{rpm}$, and current of $220-\mathrm{v})$ for providing forced convection. On the opposite site, a circular hole of $12.5 \mathrm{~cm}$ diameter was made in the centre of the solar dehydrator semi-circular curve, so that, the outside air enters the solar hydrators from the upper section and descending to the air chamber through the drying grapes before expelling out of the dehydrator as revealed in Fig. (1).

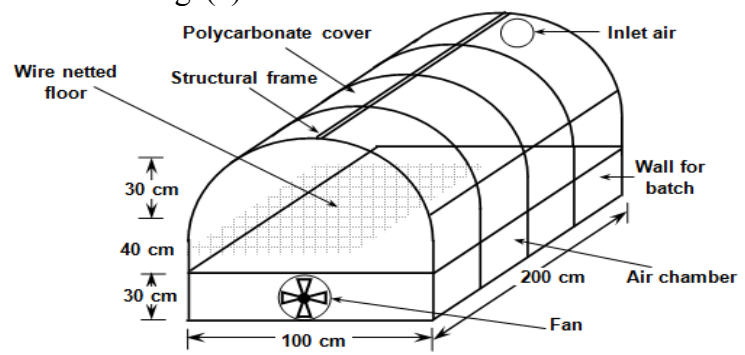

Fig. 1. Simplified scheme of solar dehydrator (modified-Quonset architectural form).

\section{Description of Natural-sun-drying system}

A natural-sun-drying mode was also carried out during this research work. It constitutes of a wooden drying tray $2.0 \mathrm{~m}$ long, and $1.0 \mathrm{~m}$ wide, with a net dehydration surface area of $2.0 \mathrm{~m}^{2}$. It was situated on an iron frame $0.40 \mathrm{~m}$ high above the ground level as clarified in Fig.(2). The upper surface of the natural sun dehydrator was cover by perforated galvanized wire mesh as well as the dehydration air chamber in the active solar dehydrator. Another wooden frame $(2.0 \mathrm{~m}$ long, $1.0 \mathrm{~m}$ wide and 0.10 $\mathrm{m}$ deep covered with a transparent sheet of polyethylene $200 \mu \mathrm{m}$ thick was situated above the wooden drying tray, to protect the grapes from contamination and reduce the risk of the outside atmospheric conditions. It was located beside the active solar dehydrator in order to compare between the two modes of dehydrating.

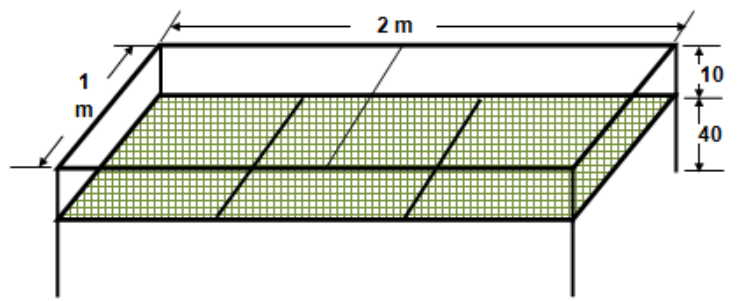

Fig. 2. Simplified scheme of Natural-sun-drying system.

\section{Description of seedless grape samples}

Fresh seedless grapes from the cultivar Thompson had purchased from a local producer of Dakhlyh Governorate during the harvesting season of 2018. The large size of grape clusters was cut into smaller pieces and the foreign impurities and immature of berries were removed. Therefore, a uniform size of grape clusters without any damaging by bacteria and fungi had selected for the experimental work. Thereafter, the grape clusters washed and cleaned using table water, and divided into an equal two groups, each one having a total fresh weight of $35.0 \mathrm{~kg}$. The dehydrating process of seedless grapes to produce raisins is a very slow process because of, the peculiar structure of grape berries, which are covered by a waxy layer. In order to remove the wax layer, induces cracking, accelerate dehydrating process, and obtain proper and smooth skin colour, the two groups of grape were subjected to chemical pretreated by submerging the grape clusters for 5 minutes in hot solution (almost $90^{\circ} \mathrm{C}$ ) comprises sodium disulfide $\left(\mathrm{Na}_{2} \mathrm{~S}_{2} \mathrm{O}_{5}\right)$ by rate of 25 grams per litre, $0.5 \%$ olive oil, and table water. Initially, 25 grams of $\mathrm{Na}_{2} \mathrm{~S}_{2} \mathrm{O}_{5}$ were mixed with one litre water inside a container until melts. Thereafter, 5 grams olive oil appended to a small amount of solution in a separate container, and then the olive-oil-solution mixture was added to the main container. After chemical pretreated, the grapes washed using table water to remove the effects of chemical manipulating.

\section{Determination of moisture content}

Five samples were randomly taken for measuring the initial moisture content according to the method 984.25 of AOAC (2000). During this mode a five simples of grape berries each one weighed 10 grams located in the preweighed petri dish using an electric digital balance that can 
measure between 0 and $600 \mathrm{~g}$ with an error rate of $\pm 0.01 \mathrm{~g}$. The five samples were dried in an electric oven at $70^{\circ} \mathrm{C}$ for $16 \mathrm{~h}$. The initial moisture contents of grapes after pretreatment were on an average of 77.19 w.b. $( \pm 0.65$ w.b.). The initial gross dimensions of grape berries included diameter, length, and weight were precisely measured using digital sliding venire calliper. Three equal grape groups each having weight of $35 \mathrm{~kg}$ with the same size of average berries of $13.86 \mathrm{~mm}( \pm 0.97 \mathrm{~mm})$ diameter, $18.29 \mathrm{~mm}( \pm 1.82 \mathrm{~mm})$ long, and 2.22 grams $( \pm 0.51 \mathrm{~g})$ weight were functioned during this study.The first group was situated inside the active solar dehydrator (ModifiedQuonset architectural form), whilst, the second group was spread on the drying tray under Natural-sun-drying conditions. The seedless grapes in each drying system were manually turned over at intervals (once each 10 hours of drying time) for uniform drying. The moisture content of grapes was continuously measured each one hour at three different locations (beginning, end, and centre of the drying systems) in order to determine the drying rate and the amount of water removal from the drying product (grapes). The air-drying speed was measured twice a day (beginning day and afternoon) throughout the experimental work using vane LCD Digital Anemometer (Montreal Canada, with range between 0 to $45 \mathrm{~m} \mathrm{~s}^{-1}$ and an accuracy of $\pm 2 \%$ for all ranges).

\section{Measurements and data acquisition unit}

The macroclimatic conditions (incident solar radiation, air temperature, relative humidity, and air speed) surrounding the two solar drying systems were precisely measured, monitored, and recoded during this study using meteorological weather station (Vantage Pro 2, Devise, USA), which located beside the dryers on a height of $5 \mathrm{~m}$. Microclimate parameters (incident solar radiation, airdrying temperature, relative humidity, bulk temperature of berry, and temperature of exhausted air) of the active solar dryer were measured and recorded using data-logger (Watch-Dog, 1000 series, USA). The microclimatic factors regularly measured every one minute and recorded during the experimental work with time interval of five minutes. The obtained data were stored on a computer file for data acquisition process.

\section{Quality of dried grapes (raisins)}

Two samples of fresh seedless grapes were randomizing taken, each one having ten berries for chemical analysis in order to determine total carbohydrate, total sugar, and vitamin $\mathrm{C}$ before the dehydration process. At regular intervals, the samples were weighted by means of a digital balance. Thereafter, these three components (carbohydrates, sugar, and vitamin C) were assessed in the dried product (raisins) after accomplished of drying process. Rehydration ratio was carried out at room temperature, when an approximate volume ratio of raisins and water was kept as 1:30 (Sing et al., 2007). The rehydration ratio of the two samples (each having ten berries of raisins), which correspond the two different modes of dehydrating process were spread on an absorbent paper for the removal of free water on the surface of berries. The change in weight was measured and recorded at constant time intervals (20 minutes). The rehydration capacity described as a rehydration ratio had computed from the ratio of sample weight after and before the rehydration using the following equation:

$$
\text { Rehydration ratio } \quad=\frac{\text { Weight of rehydrated samples }}{\text { weight of dried samples }}
$$

\section{Computer Model}

Solar drying of fresh fruit grapes mainly comprises heat and mass transfer phenomenon. The heat energy transfer includes convection, radiation, and evaporation, with external weather conditions effect involves in the ambient air temperature, intensity of solar radiation, and wind speed blowing over the solar dehydrator. The mass transfer process, which expresses the water removal rate from the product during the drying process may consider as a diffusion-controlled. The overall heat energy balance on the grapes when exposure to the solar radiation inside an active solar dehydrator is expressing in the following formula (Ramos et al., 2015):

$$
\frac{d\left(M_{i} C_{p} T_{p}\right)}{d \tau}=R_{i} A \alpha \pm \bar{h} A_{s}\left(T_{p}-T_{z i}\right) \pm A_{s} \varepsilon \sigma\left(T_{p}^{4}-T_{z i}^{4}\right)-\frac{d\left(h_{i p} M_{w}\right)}{d \tau}
$$

The left hand-side term of the above formula represents the heat energy gained by the product during the dehydration process. The right hand-side terms, respectively, are equivalent to the absorbed solar energy $\left(\mathrm{q}_{\mathrm{a}}\right)$, the heat energy loss or gain by convection, the heat energy loss or gain by radiation, and the heat energy loss by evaporation. Where, $\mathrm{M}_{\mathrm{i}}$, is the initial mass of the grapes inside the dryer in $\mathrm{kg}, \mathrm{C}_{\mathrm{p}}$, is the specific heat of the grapes in $\mathrm{J} \mathrm{kg}^{-1}{ }^{\circ} \mathrm{C}^{-1}$, $\mathrm{T}_{\mathrm{p}}$, is the bulk temperature in ${ }^{\circ} \mathrm{C}$ or $\mathrm{K}$ and, $\tau$, is the time in s. The specific heat of grapes $\left(\mathrm{C}_{\mathrm{p}}\right)$ was determined according to the bulk temperature expressed in ${ }^{\circ} \mathrm{C}$ and the moisture content (MC) at a certain time in wet basis using the following formula

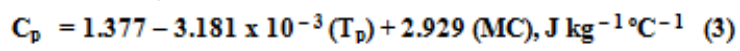

The absorbed solar energy can be computed in terms of the incident solar radiation inside the dryer $\left(\mathrm{R}_{\mathrm{i}}\right)$ in $\mathrm{W} \mathrm{m} \mathrm{m}^{-2}$, the projected area $\left(\mathrm{A}_{\mathrm{p}}\right)$ of the grapes in $\mathrm{m}^{2}$ and the absorptivity coefficient of grapes to solar radiation $(\alpha=$ 0.823 ). The heat energy loss or gain by convection can be calculated in terms of the average convection heat transfer coefficient (h) in $\mathrm{W} \mathrm{m}^{-2}{ }^{\circ} \mathrm{C}$, the surface area of grapes $\left(\mathrm{A}_{\mathrm{s}}\right)$ in $\mathrm{m}^{2}$, and the temperature difference between the bulk temperature and the drying air temperature $\left(\mathrm{T}_{\text {ai }}\right)$ in ${ }^{\circ} \mathrm{C}$. The heat energy loss or gain by thermal radiation can be estimated in terms of the emissivity factor $(\varepsilon)$, StefanBoltzmann constant $(\sigma)$ in $\mathrm{W} \mathrm{m}-\mathrm{K}^{-4}$, and the temperature difference between the bulk temperature and the drying temperature in $\mathrm{K}$. The heat energy loss by evaporation of water in terms of the latent heat of vaporization $\left(\mathrm{h}_{\mathrm{fg}}=2419 \times 10^{3} \mathrm{~J} \mathrm{~kg}^{-1}\right)$ and the mass of evaporated water during the drying process $\left(\mathrm{M}_{\mathrm{w}}\right)$ in $\mathrm{kg}$. The projected area $\left(A_{p}\right)$ and the surface area of the grapes $\left(\mathrm{A}_{\mathrm{s}}\right)$ were computed according to the initial moisture content $\left(\mathrm{MC}_{\mathrm{i}}\right)$ and average moisture content $\left(\mathrm{MC}_{\mathrm{a}}\right)$ on dry basis using the following equations (Ramos et al., 2010):

$$
\begin{array}{ll}
A_{p} & =2.00\left[0.3521+0.6314\left(\mathrm{MC}_{\mathrm{a}} / \mathrm{MC}_{\mathrm{i}}\right)\right] \\
\mathrm{A}_{\mathrm{S}} & =2.00\left[0.4054+0.5627\left(\mathrm{MC}_{\mathrm{a}} / \mathrm{MC}_{\mathrm{i}}\right)\right]
\end{array}
$$


The starting time of solar drying process $\left(h_{s}\right)$ is defining as follows (Radajewaski et al., 1990):

$$
\text { hs }=12-\frac{h_{\mathrm{d}}}{2}
$$

Where, $h_{d}$, is the hours of drying process. The heating power generated by the solar dehydrator $\left(\mathrm{H}_{\mathrm{p}}\right)$ during each hour of solar dehydrating process is computing as follows (Aghbashlo et al., 2013; Duffie and Beckman, 2013):

$$
\mathrm{H}_{\mathrm{p}}=\mathrm{m}_{\mathrm{s}} \mathrm{C}_{\mathrm{pa}}\left(\mathrm{T}_{\mathrm{ai}}-\mathrm{T}_{\mathrm{a} 0}\right), \quad \mathrm{W}
$$

Where: $m_{a}$, is the air mass flow rate through the solar dryer in $\operatorname{kg~s} \mathrm{s}^{-}$ ${ }^{1}, \mathrm{C}_{\mathrm{pa}}$, is the specific heat of drying air in $\mathrm{J} \mathrm{kg}^{-1}{ }^{\circ} \mathrm{C}^{-1}, \mathrm{~T}_{\mathrm{ai}}$, is the air temperature inside the solar dryer in ${ }^{\circ} \mathrm{C}$ and, $T_{a 0}$ is the outside air temperature in ${ }^{\circ} \mathrm{C}$. The air mass flow rate $\left(\mathrm{m}_{\mathrm{a}}\right)$ through the solar dehydrator during the drying process is calculating as follows (Montero et al., 2010; Sadodin and Kashani, 2012):

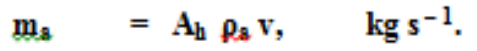

Where: $A_{h}$, is the surface area of circular hole (inlet point) $\mathbf{m}^{2}, \rho_{a}$, is the density of drying air in $\mathrm{kg} \mathrm{m}^{-3}$, and, $v$, is the speed of drying air through the solar dryer in $\mathrm{m} \mathrm{s}^{-1}$. The density of drying air $\left(\rho_{\mathrm{a}}\right)$ was determined in terms of the average air temperature between the solar drier inlet and outlet $\left(T_{m}\right)$ in ${ }^{\circ} \mathrm{C}$ as follows:

$$
\begin{aligned}
& \rho_{a}=\frac{353.44}{T_{m}+273.15}, \quad \mathbf{k g ~ m}^{-3} . \\
& \mathbf{T}_{\mathbf{m}}=\frac{T_{a i}+T_{a O}}{2},{ }^{\circ} \mathbf{C}
\end{aligned}
$$

The hourly heat energy required for heating the grape berries $\left(\mathrm{H}_{\mathrm{d}}\right)$ was calculated in terms of the exhausted air temperature from the solar $\operatorname{dryer}\left(\mathrm{T}_{\mathrm{ex}}\right)$ in ${ }^{\circ} \mathrm{C}$ as follows:

$$
\mathrm{H}_{\mathrm{d}}=\rho_{\mathrm{s}} \mathrm{C}_{\mathrm{pa}} \mathrm{Y}_{\mathrm{s}}\left(\mathrm{T}_{\mathrm{ai}}-\mathrm{T}_{\mathrm{ex}}\right), \mathrm{W}
$$

The mass of vaporized water of grapes during the drying process is computing using the following equation (Madhlopa and Ngwalo, 2006):

$$
\mathbf{M}_{w}=\mathbf{M}_{\mathbf{i}}\left[\frac{\mathrm{MC}_{\mathrm{i}}-\mathrm{MC}_{\mathrm{f}}}{100-\mathrm{MC}_{\mathrm{f}}}\right], \mathbf{k g}
$$

Where: $M_{w}$, is the mass of vaporized water of grapes in $\mathrm{kg}, \mathbf{M C}_{\mathrm{f}}$, is the final moisture content of raisins expressed in wet basis, $\%$. The thermal efficiency $\left(\eta_{\mathrm{th}}\right)$ of solar dehydrator for heating dehydration air over the ambient air during the experimental period is computing as follows (ASHRAE, 2011):

$$
\eta_{\text {th }}=\frac{H_{p}}{R A_{c}} \times 100 \quad, \%
$$

Where: $A_{c}$, is the solar dryer surface area in $\mathrm{m}^{2}$. The drying efficiency $\left(\eta_{d}\right)$ of solar dryer during the experimental period is calculating as follows_(Sadodin and Kashani, 2012):

$$
\mathbf{n}_{\mathrm{d}}=\frac{\mathrm{H}_{\mathrm{d}}}{\mathrm{R} \mathrm{A}_{\mathrm{p}}} \times 100, \%
$$

The obtained data from the experimental work during the drying process of grapes were functioned with the previous equations for analyzing and examining the drying characteristics using the Excel program. The drying model of Lewis's was functioned for describing, testing, examining, and simulating the data of grapes drying process. Recent studies reveal that the exponential model of Lewis is the simplest model to describe the moisture movement during the drying process assuming that the internal resistance is negligible. It is only taking into consideration the external surface resistance, considering that all the resistance is concentrated in an external layer of the grape berries. The Lewis's model is expressing as follows:

$$
\text { MR }=\frac{M_{t}-M_{e}}{M_{i}-M_{e}}=\exp (-k \tau)
$$

Where:

$M R=$ ratio of moisture content, dimensionless.

$M_{t}=$ moisture content at instantaneous time expressed in dry basis.

$M_{i}=$ initial moisture content expressed in dry basis.

$M_{e}=$ equilibrium moisture content expressed in dry basis.

Because of the continuous fluctuations in dehydration air temperature and the relative humidity during the solar dehydration process, the ratio of moisture content $\left(\mathrm{MR}=\mathrm{M}_{\mathrm{t}} / \mathrm{M}_{\mathrm{o}}\right)$ was functioned instead of

$$
\left(\mathbf{M R}=\left(\mathbf{M}_{\mathrm{t}}-\mathbf{M}_{\mathrm{e}}\right) /\left(\mathbf{M}_{\mathbf{i}}-\mathbf{M}_{\mathbf{e}}\right)\right)
$$

For using the mathematical simulation modeling of the solar dehydration curves (Ayensu, 1997).

\section{RESULTS AND DISCUSSION}

Fresh yields of grapes are usually greater than the immediate consumption demands, resulting in several useless of products surpluses during the short periods of harvesting and scarcity through post-harvest period. Therefore, a significant portion of the fresh yields must preserve using dehydration process immediately after harvesting, due to the dehydration is an occurring frequently technique for preservation of grapes. Solar dehydration is a common processing technology of grapes in dehydration-clean, hygienic and sanitary circumstances to national and international standards with zero energy costs. In Egypt, solar energy is the most important attractive source of heating and abundant from the renewable energy resources due to its saving energy and time, requiring less surface area, providing high level of quality, increasing the efficiency of dehydration process, and protecting the environment. There are two main modes of utilising solar energy for dehydration of seedless-grapes in order to produce raisins, natural-sun dehydration and active solar dryers. The dehydrating process was began at 14.30 on $29 / 07 / 2018$ for the two modes of dehydration (using Modified-Quonset and natural-sun-drying) and thereafter, began at 7.30 on $30 / 07 / 2018$ until the end of dehydration process. The dehydration processes were interpreted at 13.30 0n 03/08/2018 (after $49 \mathrm{hrs}$.) and at 10.30 on $05 / 08 / 2018$ (after $66 \mathrm{hrs}$.), respectively.

Solar dehydration comprehends the solar captured using solar dehydrator to rise up the dehydration-airtemperature into a desirable level for the dehydration process. Solar dehydration system, which, functioned during this research work, considered as a direct solar grapes drying. The variability of average macroclimatic and microclimatic conditions during the dehydration of seedless grapes is listed in Table (1). During the dehydration process the climatic conditions outside and inside the solar dehydrator was at the desired level and favorable. Due to the main source of heating energy during this research-work is the solar energy, which continuously changed from hour to hour and day to another according to the sky conditions (clouds and fog), and time of the day, it is sophisticated to control. During the dehydration process of seedless grapes, there were 72 hours of bright sunshine 
of which 49 hours $(68.06 \%)$ for the Modified-Quonset solar dehydrator and 66 hours $(88.40 \%)$ for the natural- sun-dehydration were measured, recorded, and used in the dehydration process.

Table 1. Hourly average air temperature outside $\left(T_{a o}\right)$ and inside $\left(T_{a i}\right)$, air relative humidity outside $\left(R H_{0}\right)$ and inside $\left(R_{H_{i}}\right)$, wind speed $\left(V_{0}\right)$, incident solar radiation outside $\left(\mathbf{R}_{0}\right)$ and inside the solar dehydrator $\left(\mathbf{R}_{\mathrm{i}}\right)$ during the dehydration process.

\begin{tabular}{lccccccc}
\hline \multirow{2}{*}{ Day } & \multicolumn{5}{c}{ Macroclimatic and Microclimatic Conditions } \\
\cline { 2 - 6 } & $\mathbf{T}_{\mathbf{a}}{ }^{\circ}{ }^{\circ} \mathbf{C}$ & $\mathbf{T}_{\text {ai }},{ }^{\circ} \mathbf{C}$ & $\mathbf{R H}_{\mathbf{0}}, \mathbf{\%}$ & $\mathbf{R H}_{\mathbf{i}}, \mathbf{\%}$ & $\mathbf{V}_{\mathbf{0}}, \mathbf{m} / \mathbf{s}$ & $\mathbf{R}_{\mathbf{0}}, \mathbf{W} / \mathbf{m}^{2}$ & $\mathbf{R}_{\mathbf{i}}, \mathbf{W} / \mathbf{m}^{2}$ \\
\hline $29 / 07 / 2018$ & $31.3 \pm 1.0$ & $41.8 \pm 5.1$ & $59.2 \pm 5.1$ & $24.5 \pm 7.1$ & $7.4 \pm 1.6$ & $455.6 \pm 183.3$ & $345.9 \pm 158.9$ \\
$30 / 07 / 2018$ & $30.7 \pm 2.3$ & $50.5 \pm 6.1$ & $63.4 \pm 8.7$ & $27.9 \pm 12.4$ & $5.7 \pm 1.8$ & $596.0 \pm 210.2$ & $520.8 \pm 223.4$ \\
$31 / 07 / 2018$ & $31.5 \pm 2.1$ & $50.4 \pm 6.9$ & $60.9 \pm 9.1$ & $25.8 \pm 12.3$ & $6.9 \pm 1.0$ & $702.3 \pm 227.1$ & $617.3 \pm 234.1$ \\
$01 / 08 / 2018$ & $30.7 \pm 2.1$ & $53.6 \pm 7.6$ & $62.7 \pm 7.6$ & $26.2 \pm 11.3$ & $6.8 \pm 1.6$ & $737.3 \pm 170.4$ & $651.8 \pm 171.5$ \\
$02 / 08 / 2018$ & $31.0 \pm 1.8$ & $52.6 \pm 6.9$ & $67.8 \pm 6.4$ & $27.6 \pm 10.3$ & $3.8 \pm 1.6$ & $696.7 \pm 209.1$ & $616.8 \pm 216.5$ \\
$03 / 08 / 2018$ & $31.3 \pm 2.1$ & $50.4 \pm 5.6$ & $68.2 \pm 8.0$ & $26.5 \pm 9.64$ & $3.8 \pm 2.0$ & $701.9 \pm 244.2$ & $610.7 \pm 252.7$ \\
$04 / 08 / 2018$ & $31.2 \pm 2.3$ & - & $65.9 \pm 10.1$ & - & $4.3 \pm 1.0$ & $707.9 \pm 245.9$ & - \\
$05 / 08 / 2018$ & $31.5 \pm 2.3$ & - & $66.0 \pm 11.2$ & - & $3.9 \pm 1.4$ & $804.6 \pm 183.6$ \\
\hline
\end{tabular}

During employing the Modified-Quonset solar dehydrator (49 hours), the hourly average incident solar radiation outside and inside that dehydrator, respectively, was $673.8( \pm 214.2)$ and $588.9 \mathrm{~W} / \mathrm{m}^{2}( \pm 220.9)$, which implemented an hourly average effective transmittance of polycarbonate cover of $87.40 \%( \pm 6.9)$. It can be observed that, the hourly average incident solar radiation during 66 hours dehydration process for the natural-sun-dehydration was $675.3 \mathrm{~W} / \mathrm{m}^{2} \quad( \pm 219.2)$. To evidently show the effect of polycarbonate cover of solar dehydrator on incident solar radiation inside the dehydrator, all the current data of incident solar radiation inside was plotted against the outside incident radiation (Fig.3). The regression analysis revealed a highly significant linear relationship $(\mathrm{r}=$ 0.9372; $\mathrm{P}=0.001$ ) between these parameters. The regression equation for the best fit was:

$$
\mathbf{R}_{\mathrm{i}} \quad=0.9061\left(\mathbf{R}_{\mathbf{0}}\right)
$$

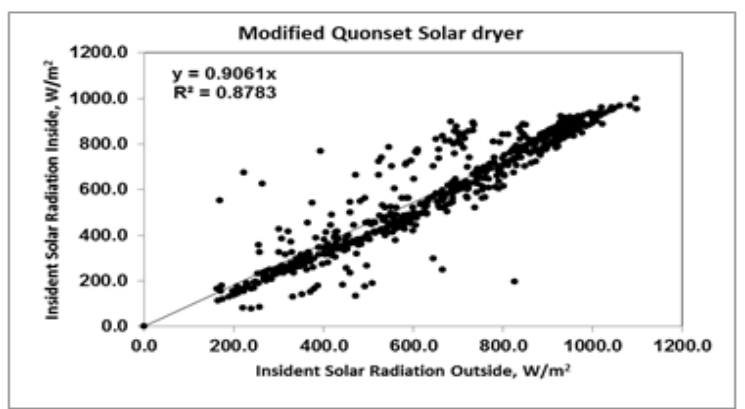

Fig. 3. Incident solar radiation inside the solar dehydrator versus incident solar radiation outside.

The hourly average air-temperatures outside and inside the solar dehydrator, respectively, were $31.1( \pm 2.0)$ and $49.9^{\circ} \mathrm{C}( \pm 10.1)$. Thus, the solar dehydrator raised the dehydrating-air-temperatures over the outside by an average of $18.8^{\circ} \mathrm{C}$. As a result, the increasing percentage in dehydration-air temperature was $61.25 \%$. The capability of dehydrating-air to carry water vapour depends on the overall thermal efficiency of the solar dehydrator in rising the dehydrating-air-temperature and consequently, in decreasing the air-relative-humidity. Therefore, the hourly average dehydrating-air-relative-humidity outside and inside the solar dehydrator, respectively, was $63.7 \%( \pm 3.6)$ and $26.4 \%( \pm 1.4)$. Consequently, the solar dehydrator lowered the dehydrating-air-relative-humidity under the outside air-relative humidity by $37.3 \%$. While, the air- relative-humidity varying between 59.2 and $68.2 \%$ with an hourly average air temperatures ranged from 30.7 to $31.5^{\circ} \mathrm{C}$ for the natural-sun-dehydration. Using solar dehydrator with forced convection, the dehydrating-air was namely heated before passing over the product being drying (seedless grapes). Therefore, the dehydrating-air is the main source of heat energy supplying into the product being drying. Therefore, the hourly average bulktemperatures of seedless grape berries inside the solar dehydrator and the natural-sun-drying, respectively, were 40.0 and $36.7^{\circ} \mathrm{C}$.

It is imperative to assess the relationship between heating power generated by the solar dehydrator $\left(\mathrm{H}_{\mathrm{p}}\right)$ and the solar energy available inside the solar dehydrator (q) to precisely evaluate the thermal performance of solar dehydrator, and determine the overall thermal efficiency. The diurnal average solar energy available inside the Modified-Quonset solar dehydrator and the heating power generated during the dehydration process (49 hrs.), respectively, was 54.939 , and $39.670 \mathrm{kWh}$. Consequently, the overall thermal efficiency of the solar dehydrator was $72.21 \%$, as a result about $27.79 \%$ of the heating power was lost with the exhausted dehydration-air. To test and examine the effect of solar energy available on the heating power generated, all the measured data of the heating power generated by the solar dehydrator during the dehydration process was plotted against solar energy available inside the dehydrator (Fig. 4). Regression analysis revealed a highly significant linear relationship ( $\mathrm{r}$ $=0.9546 ; \mathrm{P}>0.001)$ between theses parameters. The regression equation for the best fit under specific conditions was:

$$
\mathrm{H}_{\mathrm{p}} \quad=0.7118(\mathrm{q})
$$

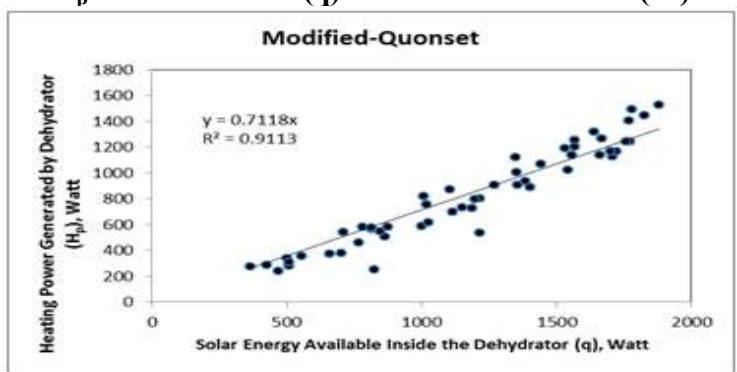

Fig. 4. Heating energy generated by the solar dehydrator against solar energy available inside the dehydrator. 
Regression analysis also reveals that, during the operating of the solar dehydrator for dehydrating seedless grapes, there was $71.18 \%$ of the total solar energy available was utilised in generating heating power. The rests of solar energy available inside the solar dehydrator $(28.82 \%)$ was lost by different modes of heat transfer (conduction, convection, radiation, and exhausted air) from the solar dehydrator into the surrounding. It is also imperative to assess the relationship between the heat energy required for heating the berries of grape $\left(\mathrm{H}_{\mathrm{d}}\right)$ and the solar energy available inside the solar dehydrator (q) to precisely evaluate the thermal performance of solar dehydrator, and determine the dehydration efficiency. The diurnal average solar energy available inside the Modified-Quonset solar dehydrator and the heat energy required for heating the grape berries during the dehydrating process ( $49 \mathrm{hrs}$.), respectively, was 54.939 , and $31.032 \mathrm{kWh}$. Consequently, the dehydrating efficiency of the solar dehydrator was $56.48 \%$. To test and examine the effect of solar energy available on the heat energy utilised in dehydration process, all the measured and monitored data of the heat energy required for the dehydration process by the solar dehydrator was plotted against solar energy available inside the dehydrator (Fig. 5). Regression analysis revealed a highly significant linear relationship $\quad(r=0.9276 ; P>$ 0.001 ) between theses parameters. The regression equation for the best fit under specific conditions was:

$$
\mathrm{H}_{\mathrm{p}} \quad \mathbf{0 . 5 9 5 1}(\mathrm{q})
$$

Regression analysis also clarified that, during the operating of the solar dehydrator for dehydration seedless grapes, there was $59.51 \%$ of the total solar energy available was utilized in the dehydrating process. The regression equation also shows that, the slope almost equal to the dehydration efficiencies of the solar dehydrator. The heat energy balance on the product being dehydration comprised two essential components; input and output heat energy. The input component corresponded to the rate of heat energy acquired by the product being dehydration $\left(\mathrm{q}_{\mathrm{g}}\right)$. The output components identifies; the absorbed solar radiation by the product $\left(\mathrm{q}_{\mathrm{a}}\right)$, heat energy loss or gain by convection ( $\mathrm{q}_{\text {conv. }}$ ), heat energy loss by evaporation of moisture content $\left(\mathrm{q}_{\mathrm{ev}}\right)$, and heat energy loss or gain by radiation $\left(\mathrm{q}_{\mathrm{rad}}\right)$. These components and their effect on dehydration of seedless grapes for the solar dehydrator during the experimental work are summarized and listed in Table (2).

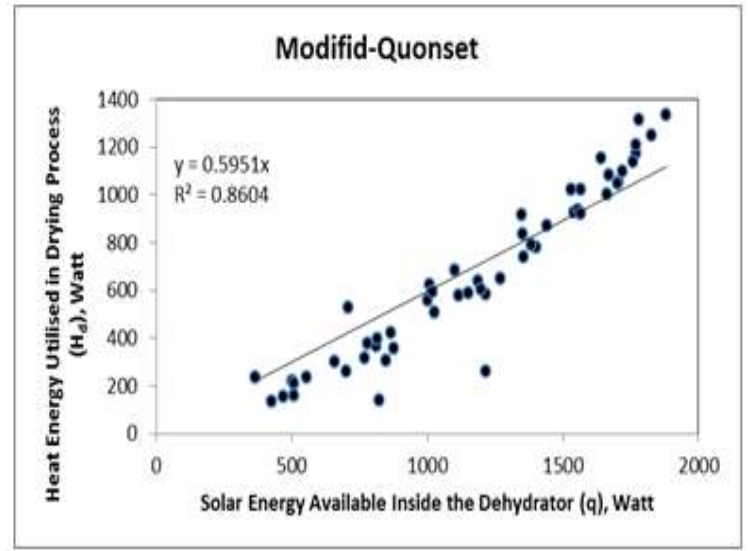

Fig. 5. Heat energy utilised in dehydration process against solar energy available inside the solar dehydrator.

Table 2. Hourly average heat energy gained by the grapes $\left(q_{g}\right)$, absorbed heat energy $\left(q_{\mathrm{a}}\right)$, convective heat gain $\left(q_{\text {conv }}\right)$, evaporative heat loss $\left(q_{\mathrm{ev}}\right)$, and radiation heat gain $\left(q_{\mathrm{rad}}\right)$ inside the solar dehydrator during the dehydration process

\begin{tabular}{lccccc}
\hline Day & $\mathbf{q}_{\mathbf{g}}, \mathbf{W a t t}$ & $\mathbf{q}_{\mathbf{a}}, \mathbf{W a t t}$ & $\mathbf{q}_{\mathbf{c o n v}} \mathbf{\%}$ & $\mathbf{q}_{\mathbf{e v}}, \mathbf{W a t t}$ & $\mathbf{q}_{\mathbf{r a d}}, \mathbf{W a t t}$ \\
\hline $29 / 07 / 2018$ & $1081.3 \pm 51.2$ & $624.5 \pm 182.0$ & $352.8 \pm 261.4$ & $578.9 \pm 90.8$ & $117.5 \pm 90.5$ \\
$30 / 07 / 2018$ & $998.4 \pm 147.5$ & $857.3 \pm 367.8$ & $369.2 \pm 186.1$ & $586.2 \pm 254.9$ & $131.8 \pm 74.8$ \\
$31 / 07 / 2018$ & $643.3 \pm 74.8$ & $1016.1 \pm 385.4$ & $408.3 \pm 191.2$ & $408.8 \pm 192.7$ & $143.9 \pm 73.2$ \\
$01 / 08 / 2018$ & $452.4 \pm 44.9$ & $1072.8 \pm 282.3$ & $399.1 \pm 195.3$ & $231.8 \pm 133.9$ & $143.9 \pm 74.7$ \\
$02 / 08 / 2018$ & $310.7 \pm 48.8$ & $1015.2 \pm 356.3$ & $382.7 \pm 201.7$ & $192.1 \pm 85.0$ & $143.0 \pm 80.5$ \\
03/08/2018 & $211.0 \pm 24.9$ & $1005.2 \pm 415.9$ & $376.5 \pm 206.1$ & $126.7 \pm 14.8$ & $143.8 \pm 89.8$ \\
\hline Mean SD & $616.2 \pm 359.9$ & $974.9 \pm 354.5$ & $381.4 \pm 192.7$ & $333.8 \pm 227.6$ & $139.9 \pm 75.8$ \\
\hline
\end{tabular}

The hourly average heat energy gained by the seedless grapes (input heat energy) during the dehydration process was gradually diminished due to reduction in moisture content of the product being drying, which induced in decreasing both the total mass of seedless grapes and the specific heat of grapes. Accordingly, the heat energy gained decreased from 1081.3 Watt $( \pm 51.2)$ into 211.0 Watt ( \pm 359.9). Due to the heat energy absorbed by the seedless grapes depending upon the intensity of incident solar radiation on the berries of grape, which changed from hour to hour and day to another according to the climatic conditions, it was varied with the time of dehydration. The heat energy acquired by convection was changed from hour to hour and day to another depending on the temperature difference between the berries of grape and the dehydrating-air as revealed in Table (2). The heat energy loss by evaporation of water was gradually diminished from 578.9 Watt $( \pm 90.8)$ to 126.7 Watt $( \pm 14.8)$ due to reduction in moisture content of the seedless grapes. The heat energy gained by radiation was also changed from hour to hour and day to another depending also on the temperature difference between the berries of grape and the dehydration-air. Applying the mathematical model of the overall heat energy balance on the seedless grapes achieved an hourly average input heat energy of 616.2 Watt ( \pm 359.9$)$ and an hourly average output heat energy of 1114.8 Watt $( \pm 657.8)$. The difference between the input and output heat energy 498.6 Watt corresponded the heat energy stored in the berries of seedless grapes. A combined regression analysis using data of heat energy input and output for the solar dehydrator clarified that, a highly significant relationship between these parameters 
as the highest coefficient of determination $\left(\mathrm{R}^{2}=0.9321\right)$ was achieved. The combined regression equation for the best fit was:

$$
\left.\mathrm{q}_{\mathrm{g}}=\mathbf{0 . 1 3 1 8}\left(\mathrm{q}_{\mathrm{a}}\right)+\underset{\left(\mathrm{q}_{\mathrm{rad}}\right)}{\operatorname{4.2132}\left(\mathrm{q}_{\text {conv. }}\right)}\right)+1.2097\left(\mathrm{q}_{\mathrm{ev}}\right)-11.6083
$$

The initial moisture content after pre-treatment ranged from 75.65 to $79.28 \%$ w.b. with an average initial moisture content of 77.19 w.b. ( $\pm 0.65 \mathrm{wb})$. The initial and final moisture contents, dehydrating time, and the drying rates of seedless grapes for the two different modes of dehydration process during the experimental work are summarized and listed in Table (3). During the dehydrating process, the time of dehydration for the solar dehydrator and natural-sun-dehydration, respectively, was 49 and 66 hours. Accordingly, the solar dehydrator was taken lower dehydration time as compared with the natural-sundehydration. These differences occurred due to the variation in dehydration conditions (intensity of solar radiation, dehydration-air-temperature, and air-relative humidity) between the two modes of dehydration processes. Variations in dehydrating rates were also observed during the experimental work. The solar dehydrator was achieved dehydration rate of $574.7 \mathrm{~g} / \mathrm{hr}$., whilst, the dehydration rate of the natural-sun-dehydration was $434.1 \mathrm{~g} / \mathrm{hr}$. The transformation of fresh grapes $(35 \mathrm{~kg}$ ) into raisins for the solar dehydrator and natural-sun-drying was 6.840 and $6.785 \mathrm{~kg}$, respectively. Accordingly, each one kilogram of raisins requires 4.902 and $5.158 \mathrm{~kg}$ of fresh grapes, respectively. The previous obtained data are in agreement with that data published by Ramos et al. (2015); Adiletta et al. (2015) and Baradey et al. (2016). The obtained simple exponential equations, which precisely described the behaviour of the experimental data using solar dehydration processes of seedless grapes for the two different modes of dehydration, clarified a highly significant relationship between the measured and calculated moisture contents during the experimental work as showed in Fig. (6). Applying the simple model (Lewis's model) gave a satisfactorily dehydration behaviour as expressly revealed from the coefficient of determination values $\left(R^{2}=0.9845\right.$ and $R^{2}=0.9954$, respectively) and standard error values $(\mathrm{SE}=0.2678$ and $\mathrm{SE}=0.2592$, respectively). Therefore, the description of solar dehydrating substantially identified the Lewis's model.

Table 3. Initial and final moisture contents, dehydrating time, and dehydrating rate of seedless grapes and raisins during the experimental work

\begin{tabular}{lcc}
\hline Measurement & $\begin{array}{c}\text { Solar } \\
\text { dehydrator }\end{array}$ & $\begin{array}{c}\text { Natural-sun- } \\
\text { drying }\end{array}$ \\
\hline Initial moisture content (w.b.), \% & 77.19 & 77.19 \\
Final moisture content (w.b.), \% & 15.78 & 16.00 \\
Dehydrating time, hr. & 49 & 66 \\
Dehydrating rate, g/hr. & 574.7 & 434.1 \\
Raisins produced from 35 kg & 6.840 & 6.785 \\
\hline
\end{tabular}

One of the objectives of this study for dehydration seedless grapes using the solar dehydrator (ModifiedQuonset architectural form) and the natural-sundehydration is to investigate the effect of dehydration process on the quality of final product (raisins). Four different physical and chemical were examined, measured and recorded prior and after the dehydrating process for the two different methods of dehydration operations. The percentages of water activity for two modes of dehydration, respectively, were $92.88 \%$ and $92.97 \%$. The most important properties functioned to measure the quality of raisins is the rehydration ratio The rehydration ratio is dependent upon the structural changes in vegetal tissues and cells of grape berries during the dehydrating process, which induces in shrinkage, collapse and reduces the capacity of water absorption. Consequently, it induces in preventing the complete rehydration of the raisins. After 400 minutes of testing, it observed that, the rehydration ratio for the solar dehydrator and natural-sun-drying, respectively, was 2.806 and 2.499. Therefore, samples previously dehydrated over longer times (66 hours) gave lesser rehydration ratio. The obtained data is in agreement with that published by Gabas et al. (2009) and Russo et al. (2013).
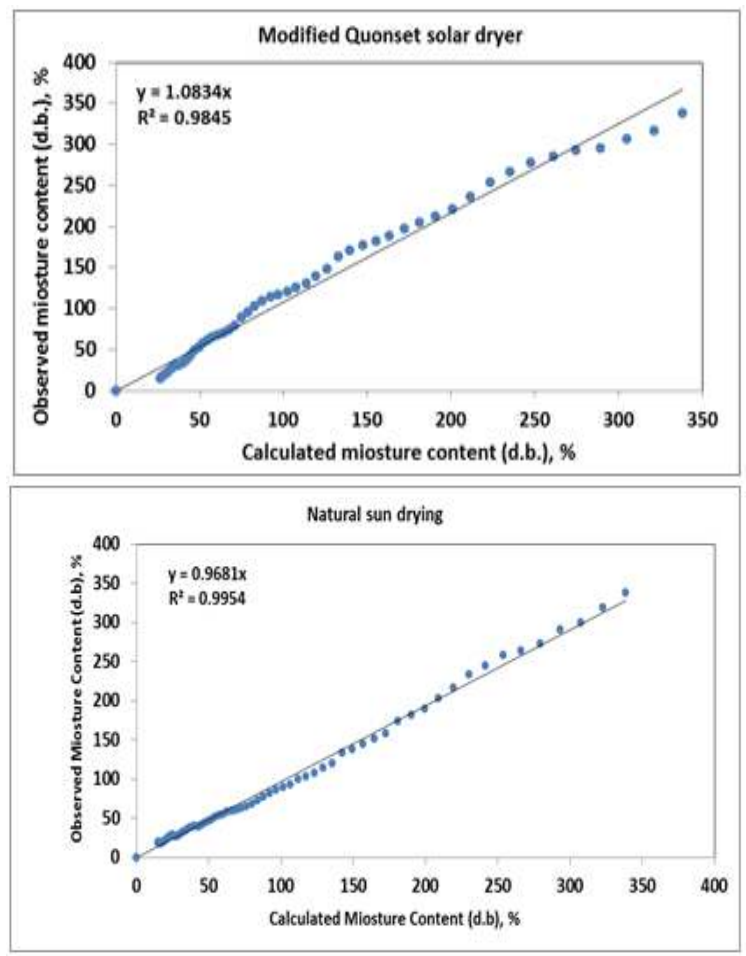

Fig. 6. Observed moisture content versus calculated moisture content using Lewis's model for the two different modes of dehydration.

Raisins are a rich source of carbohydrates content, thus the total carbohydrates contained in the fresh seedless grapes $(462.4 \mathrm{mg} / \mathrm{g})$, respectively, were decreased into 393.71 and $339.70 \mathrm{mg} / \mathrm{g}$ due to dehydrating process. Accordingly, the total carbohydrates contained in raisins produced by the solar dehydrator were higher than that produced by the natural-sun-dehydrating process by $15.90 \%$. These differences probably occurred due to the longer dehydrating time required for the natural-sundehydrating. Total sugars contained in the raisins were also affected by the dehydration process for the two different modes. The percentage of total sugars contained in the 
fresh grapes $(10.62 \%)$ was increased in raisins and reached into $12.03 \%$ and $11.87 \%$ for the two different methods of dehydration, respectively. This behaviour was probably occurred because of, reduction in the moisture content after dehydrating process. Nevertheless, reduction in concentrated of total sugars contained was observed during the dehydrating process, which probably caused by nonenzymatic browning reactions. The concentration of sugar contained in fresh grapes $(409.8 \mathrm{mg} / \mathrm{g})$, respectively, was reduced in raisins and reached into 341.32 and 329.68 $\mathrm{mg} / \mathrm{g}$ as revealed in Fig. (7), consequently, a reduction of $16.71 \%$ and $19.55 \%$ occurred for the two different modes of dehydrating processes, respectively. A reduction in main contained of Vitamin C (total ascorbic acid) was also observed between the fresh grapes and the raisins as affected by the dehydration processes and dehydration time for the two different methods of drying. Main contained of Vitamin $\mathrm{C}$ in raisins was affected by the drying process with a $24.61 \%$ and $35.28 \%$ reduction for the two different modes of drying, respectively. These data are in agreement with the data published by several investigators (Cinquanta et al., 2002; Carranza-Concha et al., 2012; Adiletta et al., 2015).

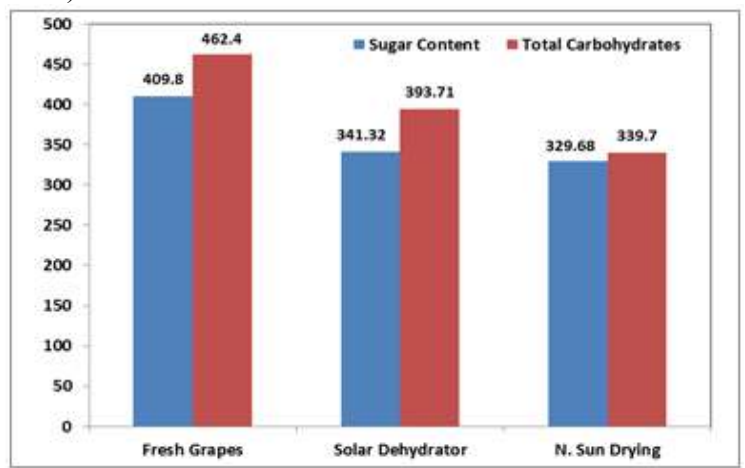

Fig. 7. Total carbohydrates and sugar contained before and after the dehydration process for the two different modes of dehydration processes.

\section{CONCLUSION}

Comparison of drying characteristics of pretreated seedless grapes using two different modes of solar dehydration (solar dehydrator and natural-sun-drying) was investigated. The moisture content was removed by the solar heated air having temperature ranged between 40 and $60^{\circ} \mathrm{C}$, air-relative-humidity from 15 to $49 \%$, and incident solar radiation from 250 to $1035 \mathrm{~W} / \mathrm{m}^{2}$. Therefore, the sensible and latent heat of evaporation of water was carried on by water vapour, which exhausted out the solar dehydrators using two suction blowers. Thus, it was possible to dry pretreated seedless grapes using solar energy under favorable microclimatic conditions. Dehydration proceeded successfully under different weather conditions in the solar dehydrator. Final moisture contents were within desirable levels for safe stored of raisins which were also of high nutritional quality. Ultimately, the solar dehydrator was transformed fresh grapes into raisins with high level of quality as compared with the natural-sun-dehydration.

\section{REFERENCES}

Abdellatif, S. M.; El-Hadidi, Y. M.; and Mohammed, E. M. (2015) "Thermal performance analysis for solar collector air heater assisted solar Modified-Quonset dryer" Journal of Soil Sciences and Agricultural Engineering, Mansoura University, Vol. 6, No. (10): $1217-1236$.

Adiletta, G.; Senadeera, W.; Liguori, L.; and Crescitelli, A. (2015) "The influence of abrasive pretreatment on hot air drying of grape" Food and Nutrition Sciences, 6: 355 - 364

Aghbashlo, M.; Mobli, H.;Rafiee, S.; and Madadlou, A. (2013) "a review on exergy analysis of drying processes and systems" Renewable and Sustainable Energy reviews, 22: $1-22$.

AOAC, Method 984.25 (2000) "Official methods of analysis" $17^{\text {th }}$ ed. Gaithersburg: AOAC International

ASHRAE (2011) "American Society of Heating, Refrigerating and Air-conditioning Engineers" Fundamentals Handbook, Atlanta, USA

Ayensu, A. (1997)."Dehydration of food crops using a solar dryer with convective heat flow". Solar Energy; 59(4-6):12-16.

Baradey. Y; Hawlader, M. N. A.; Ismail, A. F.; Hrairi, M.; and Rapi. M. I. (2016) "Solar drying of fruits and vegetables" International Journal of Recent Development in Engineering and Technology, Vol. (5): $1-6$

Carranza-Concha, J.;Benlloch, M.; Camacho, M. M.; and Martinez-Navarrete, N. (2012) "The influence of drying air temperature on the physical properties of dried and rehydrated eggplant" Food and Bioproducts Processing, 90: 249 - 256.

Cinquanta, L.; Di Matteo, M.; and Esti, M. (2002) "Physical pre-treatment of plums (prunus domestica), Part 2, Effect on the quality characteristics of different prune cultivars" Food Chemistry, 79: $233-238$

Duffie, J. A.; and Beckman, W. A. (2013) "Solar Engineering of Thermal Processes" $5^{\text {th }}$ edition, John Wiley and Sons New York, N.Y., USA

FAO, (2017) "Food Loss and Waste Reduction and Value Chain Development for Food Security in Egypt and Tunisian" GCP/RNE/004/ITA - 2

Fudholi, A.; Othman, M. Y.; Ruslan, M. H.; Mat, S.; and Sopian, K. (2013) "Prospect and future of solar dryer for agricultural and marine products: perspective Malaysia" In process of the seventh WSEAS International Conference on Renewable Energy Sources, $141-149$.

Fudholi, A.; Sopian, K.; Bakhtyar, B.; and Gabbasa, M. (2015) "Review of solar drying systems with air based solar collectors in Malaysia" Renewable and Sustainable Energy Reviews, 51: 1191 - 1204

Gabas, A. L.; Menegalli, F. C.; and Telis-Romero, J. (2009) "Effect of chemical pre-treatment on the physical properties of dehydrated Grapes" Drying Technology, 17: 1215 - 1226. 
Jairaj, K. S.; Singh, S. P.; and Srikant, K. (2009) "A review of solar dryers developed for grape drying" Solar Energy, 83: 1698 - 1712.

Kumar, M.; Sansaniwal, S. K.; and Khatak, P. (2016) "Progress in solar dryer for drying various commodities" Renewable and Sustainable Energy Review, 55: 346 - 360.

Madhlopa, A.; and Ngwalo, G. (2006) "Solar dryer with thermal storage and biomass-backup heater" Solar energy, 77: $151-164$.

Montero, I.; Blanco, J.; Miranda, T.; Rajas, S.; and Celma, A. R. (2010) "Design, construction and performance testing of a solar dryer for agroindustrial by-products" Energy Conversion and Management, 51(6): 657 - 667.

Radajewski, W; Gaydon, D.; and McGahan, E. J. (1990) "Optimization of solar hay drying in a step-flow dryer" Transactions of the American Society of Agricultural Engineers, Vol. 35(5): 1423-1431.

Ramos, I. N.; Miranda, J. M. R.; Brandao, T. R. S.; and Silva, C. L. M. (2010) "Estimation of water diffusivity parameters on grape dynamic drying" Journal of Food Engineering, 97: 504-519
Ramos, I. N.;Brandao, T. R. S.; and Silva, C. L. M. (2015) "Simulation of solar drying of grapes using an integrated heat and mass transfer model" Renewable Energy, 81: 896-902.

Russo, P.; Adiletta, G. ; and Di Matteo, M. (2013) "The influence of drying air temperature on the physical properties of dried and rehydrated Eggplant" Food and Bio-products Processing, 91: 249-256.

Sadodin, S. and Kashani, T. T. (2012) "Numerical investigation of a solar greenhouse tunnel drier for drying of copra" Renewable Energy, 35: 83 - 90.

Singh, B.; Panesar, S. P.; and Nanda, V. (2007) "Rehydration kinetics of Un-Osmosed and PreOsmosed carrot cubes" World Journal of Dairy and Food Sciences, 2: $10-17$.

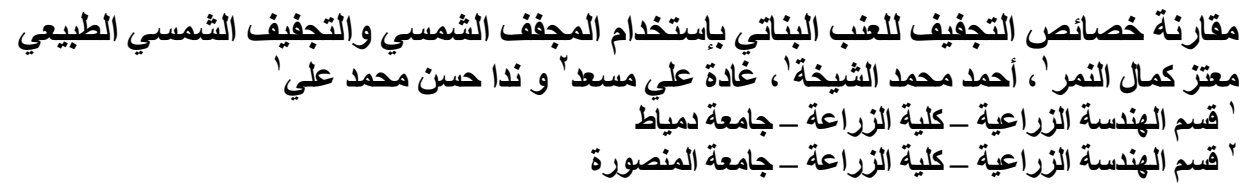

تهدف هذه الدر اسة إلى مقارنة خصائص التجفيف للعنب البناتي المعامل كيميائياً بإستخدام نظامي تجفيف مختلفين وهما التجفيف الثمسي

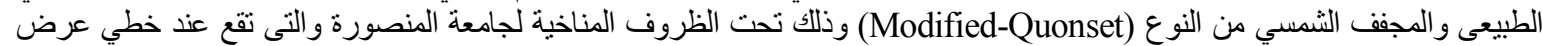
31.352º E كان 31.043º N

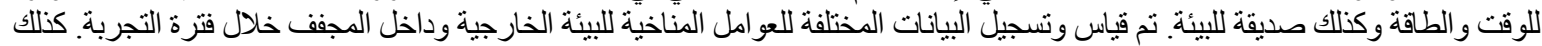
تم تقييم كلاً من الآداء الحرارى للمجفف الثمان الثمسى وخصائص التجفيف لطبقة رقيقة من العنب البناتى وجودة الزبيب الناتج من عملية التجفيف.

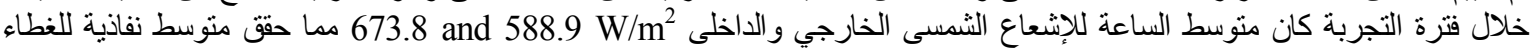
مقدار ها \%

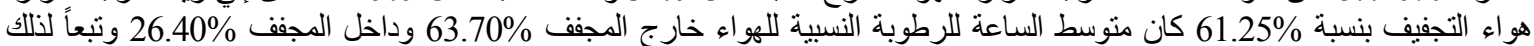

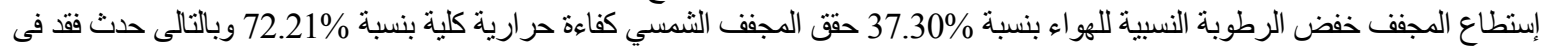

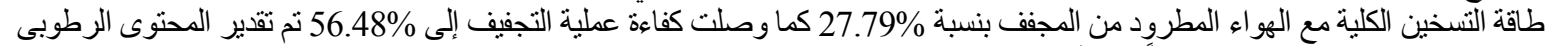

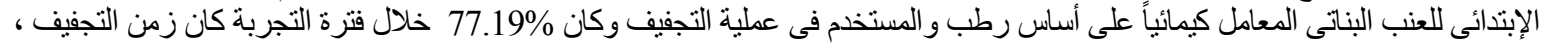

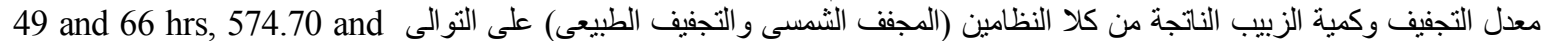
4.902434 .10 g/hr, and 6.840 and 6.785 kg of raisins أدى التجفيف بإستخدام المجفف الثمس إلى زيادة نسبة التشرب بمعدل 5.158 kg of grapes الطبيعى. نتيجة لعملية التجفيف إنخفض محتوى الكربوهيدرات فى العنب المعامل كيمائياً من 393.71 and 339.70 إلى mg/g في الزبيب المجفف بكلا النظامين على التوالى. إنخفض نركيز السكر فى العنب من

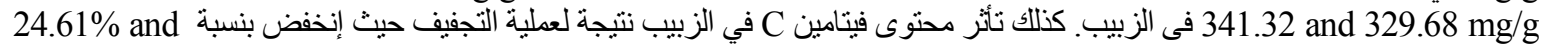
35.28\% فى كلا النظامين علي التو الى. 